\title{
CANCER MORTALITY AND INCIDENCE IN SLOVAKIA AND THEIR
}

\section{SPATIAL SPECIFICS}

DOI: http://dx.doi.org/10.18509/GBP.2015.64

UDC: 616-006.6-036.8(437.6)

\author{
RNDr. Katarína Vilinová, PhD. \\ RNDr. Gabriela Repaská, PhD. \\ Doc. RNDr. Alena Dubcová, CSc. \\ RNDr. Jana Némethová, PhD.
}

Constantine the Philosopher University in Nitra, Faculty of Natural Sciences, Department of Geography and Regional Development, Slovakia

\begin{abstract}
Managing the prevention, diagnosis and therapy of cancers is a difficult medical task with permanent consequences for the development of population health status and the economy of health of care of each country. Its incidence is increasing worldwide. Cancer stands for more than 70 diseases caused by uncontrolled division of cells in various tissues. The key indicators for tracking cancers include mortality, incidence as well as prevalence. Tackling the issue of development of incidence can be considered relevant topic of geographical research. We can agree with the opinion that the fight against neoplasms, in order to be comprehensive, must involve in itself the spatial aspect which is best applied especially in the field of medical geography. The paper aims to analyze and evaluate the cancer incidence and mortality in Slovakia. The result of these partial analyses is an assessment of the situation from the perspective of selected indicators. In the paper, will use the method of analysis and synthesis as well as graphical, mathematical-statistical, and cartographic methods.
\end{abstract}

Keywords: Slovakia, cancers, mortality, incidence, regional disparities

\section{INTRODUCTION}

Oncological disease mortality has globally an increasing trend. The World Health Organization estimates that, compared to 12 million of newly registered cases of cancer at present, in 2025 there will be more up to 20,000,000 [4]. According to the estimates of WHO, up to $72 \%$ of all cancer deaths occurred in low and medium developed countries. Gradually, the increase of mortality from cancers can be observed also in Slovakia. This kind of disease is often a reflection of improper lifestyle, stress as well as other determinants leading to this disease.

\section{CANCER DISEASES}

The cancer incidence has globally an increasing trend, which can also be seen in Slovakia. More than 99\% of cancers, for which the Slovak population died in 2013, were malignant cancers. Therefore, cancer is the second leading cause of death in Slovak population right after the cardiovascular diseases. It is due to several reasons which include - increase in life expectancy, wrong lifestyle as well as population growth and real increase in cancer incidence. Cancers belong to the important problem of the whole society which is significant for the viewpoint of high incidence, frequency of disability, and high mortality. As reported by [10], they endanger mostly middle-aged and older people by its incidence and deadly potential. Given the development of the malignant cancer incidence as well as prognoses of population development in Slovakia (population aging, increase 
in life expectancy, etc.), we have to count with increasing cancer incidence. According to statistics on the Slovak population, there is more than 25,000 new cases of cancer while almost $70 \%$ of them occur in the population over 60 years [9]. Since the Slovak population is one of the fastest aging in Europe, it is necessary to find solutions for improving the conditions for an active life of especially older people and quality of their life.

Due to the population aging, most of developed countries face health and clinical problem [11]. Surviving with cancers in last decade has improved significantly due to recent advances in the treatment and diagnosis in the early clinical stages. 10-yeatr survival rate of adults is approaching 59\% and 75\% regarding children. Patients with cancer diseases live longer and they are exposed to other co-morbidities including subsequent primary neoplasms [2]. In the population of 20-34 year olds in the US, it is estimated that one patient out of 570 persons survives with a cancer from childhood [3].

Spatial disparities world diseases characterized [1]. A comprehensive approach to the population health status in Slovakia through sickness rate but also mortality is provided by Vilinová [12]. On the example of extending the mortality of men for Prostate cancer at the level of districts in Slovakia, this topic is analyzed in detail by [5]. The characteristics of individual cancer types in the Czech Republic analyze [6, 7].

While watching the structure of mortality according to causes in Slovakia, we can observe the same structure of mortality for men, women as well as the total mortality. The structure of mortality by causes is clearly dominated by circulatory system diseases which took the first position in the causes of death in 1996 (55\%) but also in 2013 (50\%).

However, the Slovak population during the studied years often died to another cause and that was cancers. Overall mortality from cancers reached in 1996 the level of $22 \%$ which was less by 4\% compared to 2013 (Fig. 1). Therefore, we can claim that cancers as civilization diseases record an increasing trend in Slovakia. The share of mortality from cancers is, however, different in terms of gender structure. A higher share of mortality from this cause was observed in men. Out of the total number of deaths of men, the proportion of deaths from cancer reached $25 \%$ in 1996. By 2013, this share increased to the value of $29 \%$. The situation in mortality of women from cancers is very similar. It is the second most common cause of their mortality. An increasing share of deaths from this disease is visible because in 1996, the mortality reached the value of 19\%, but in 2013 it was $21 \%$ (Fig. 2).

Another indicator for monitoring cancers is the crude mortality rate for cancers studied in men and women. Six regions of Slovakia reached the mortality rate for cancers greater than 250.6/100 thousand men. More positive position in this indicator is for women. Four regions of Slovakia, which are located in the eastern and northern parts of Slovakia, are characterized by the crude mortality rate which was lower than the $160.5 / 100$ thousand women. In terms of nationwide perspective on the crude mortality rate for cancer, we can see that, particularly, in the Nitra and Trnava Self-governing Regions, there is a very unfavorable situation. 


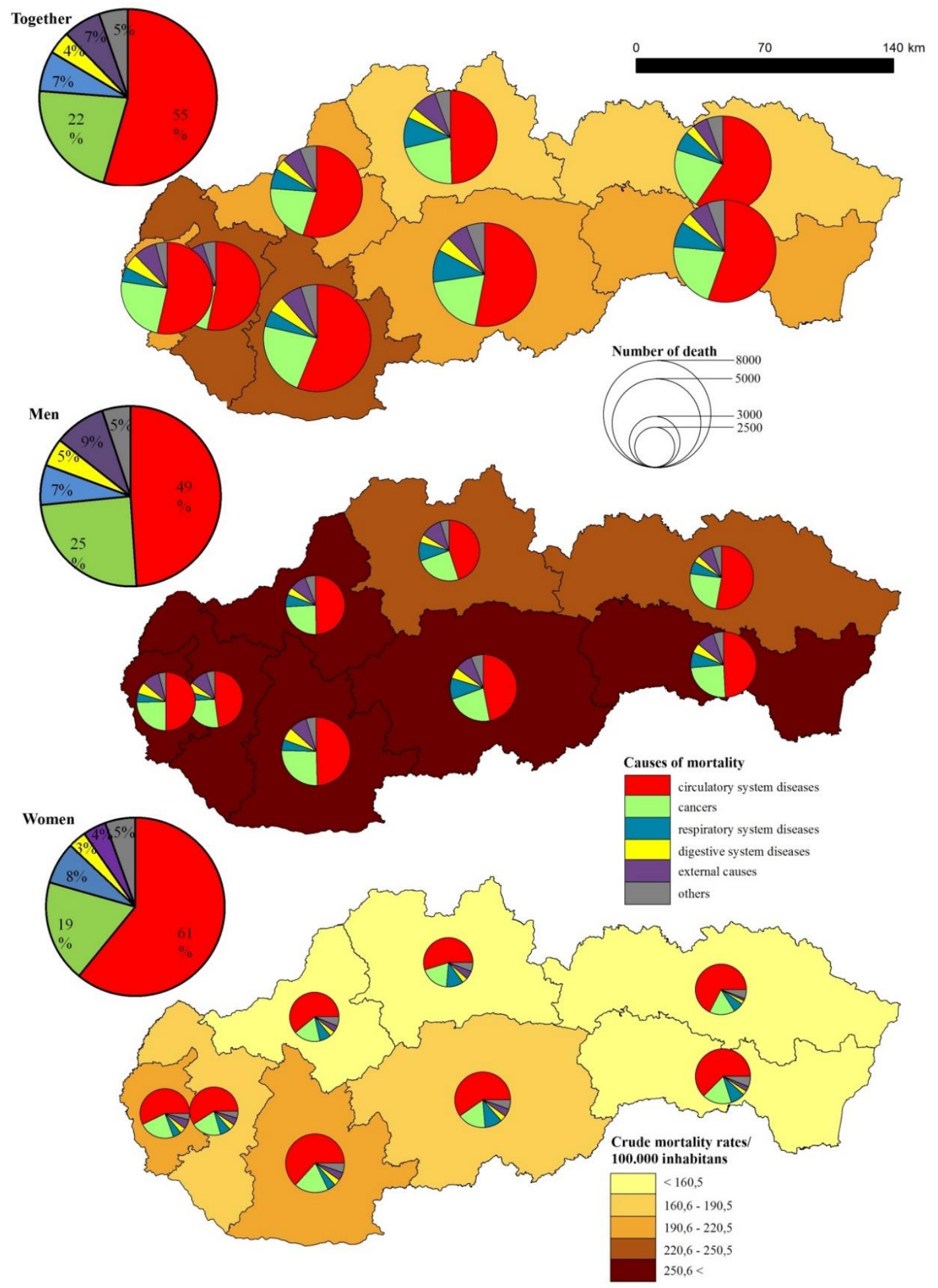

Fig. 1. Structure of mortality according to the death causes in Slovakia (1996) 


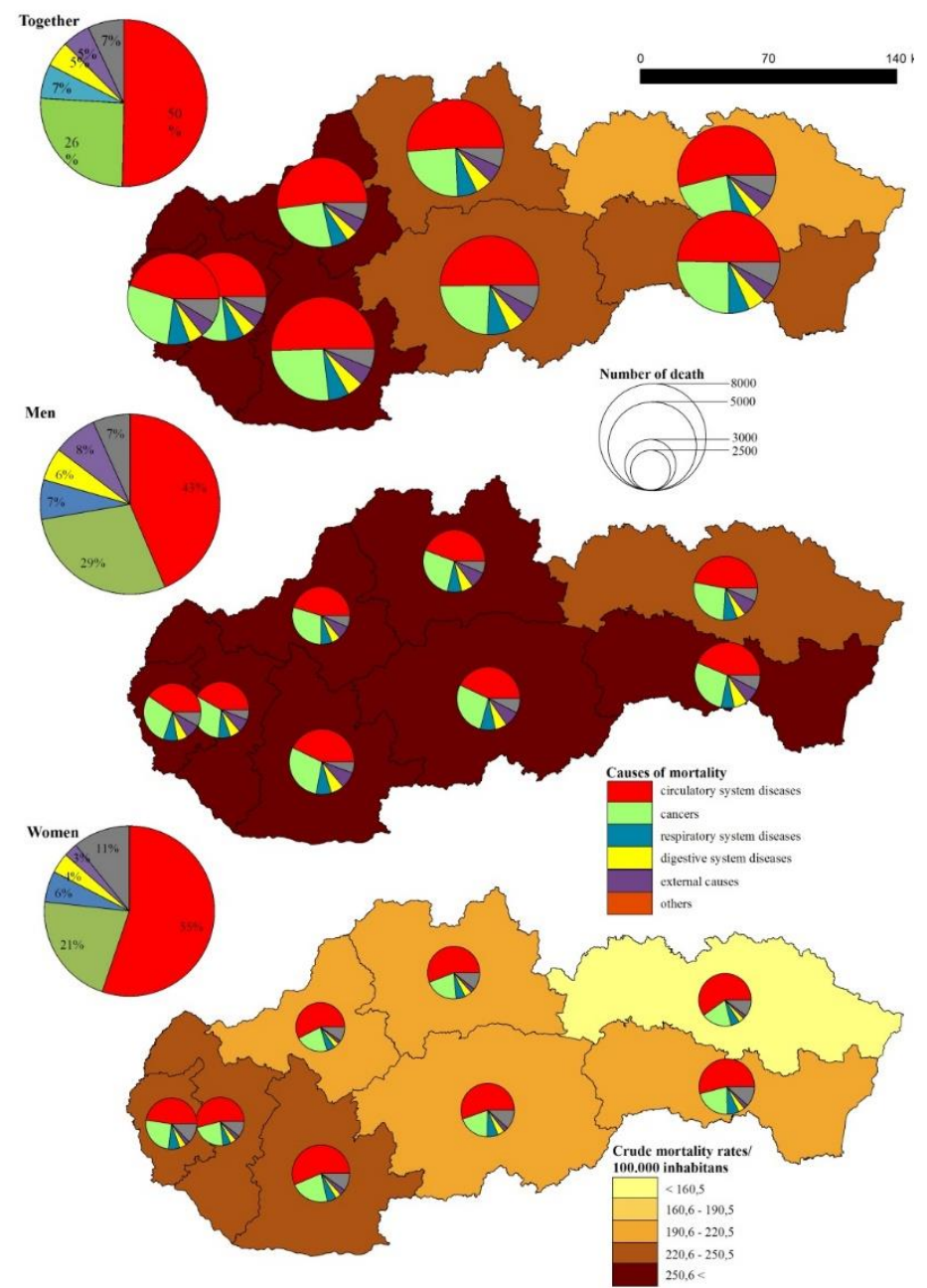

Fig. 2. Structure of mortality according to the death causes in Slovakia (2013)

In addition to the crude rate, specific measurements of cancer occurrence include its incidence. Incidence is defined as the number of new diseases that occurred within a certain time period to the total size of the population at risk. We consider it a direct estimation of probability or risk of the creation of disease over a defined period. The issue of monitoring the development of cancer incidence in Slovakia is challenging due to the insufficient processing of data of this indicator since it is processed only up to the year 2008. The cancer crude incidence rate in Slovakia has an upward trend in the period of 1996-2008 with the exception of slight decreases in 1999, 2000, and 2006 (Fig. 3). The most significant increase in this indicator is observed from 2006 to 2008 which is related to the growing trend of development of cancers. In general, the level of cancer crude incidence rate in Slovakia increased from 306.9/100 thousand people in 1996 to 375.3/100 thousand people in 2008. The crude incidence rate for men reaches significantly higher values compared to women. We can say that the highest cancer crude incidence rates in Slovakia were recorded in 2008, which is very unfavourable in the long term. 


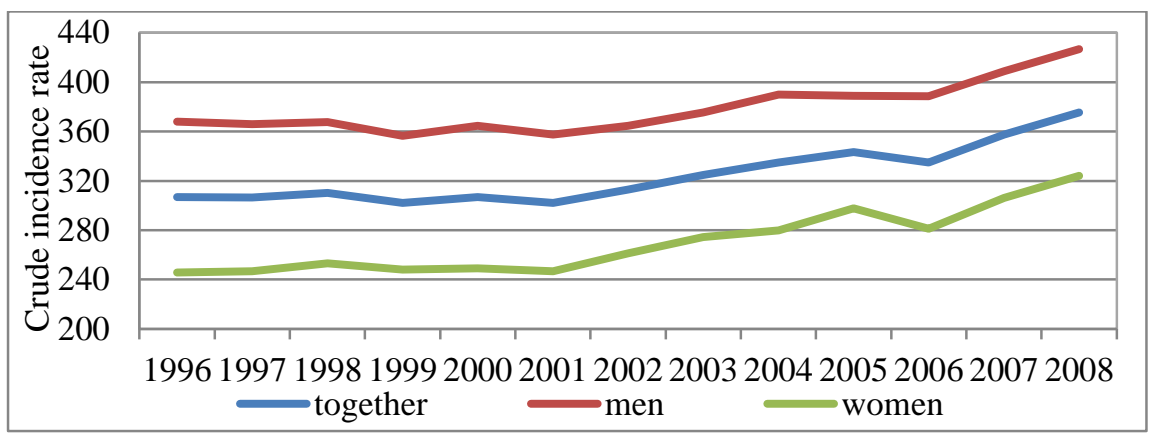

Fig. 3. Development of cancer crude incidence rate in Slovakia (1996-2013)

In terms of crude incidence rate in the regions of Slovakia, the situation is significantly differentiated which is reflected in spatial disparities. Overall, the highest crude incidence rate for the studied period is located in the Bratislava Self-governing Region with the values of 699/100 thousand people in 2008. It is followed by the Nitra Self-governing Region with the value of $623 / 100$ thousand people. A very positive situation is in the Prešov Self-governing Region because the crude incidence rate reached the value of 465/100 thousand people.

Another important indicator for monitoring cancers is the standardized incidence. Incidence values are calculated by the direct method to the world standard population. It is an indicator that allows comparison not only at regional, but also at global level. The development of standardized incidence in the regions of Slovakia is documented in Fig. 4. The higher level of standardized incidence is observed in men with a very unfavorable condition, especially, in the Bratislava Self-governing Region. In this region, the values reached 478/100 thousand people which was in 2008 a maximum value for the studied period. The Bratislava Self-governing Region is specific also with high values in terms of standardized incidence of women which reached the highest values from all regions of Slovakia. In 2008, the incidence of women in this region reached the level of 378/100 thousand people.

The most balanced progress in the development of cancer incidence is observed in the Prešov, Košice and Žilina Self-governing Regions. However, the incidence had significantly increasing character in the Trnava, Trenčín and Bratislava Self-governing Regions. We have to consider also the fact that the time development of the incidence reflects, in addition the actual situation in the population, also a number of factors and influences which are related to its monitoring and registration of cancers such as changes in classifications. Regional incidence is influenced mainly by differences in the demographic structure of the population and its living conditions in different regions. The possibility and nature of the treatment of oncological diseases is in the regions of Slovakia conditional by the overall situation in the health sector. Network of oncological facilities in Slovakia provides patients with a wide range of system therapy. Specialised cancer institutes in Slovakia include e.g. the National Cancer Institute in Bratislava, St. Elizabeth Cancer Institute in Bratislava, East Slovakia Cancer Institute in Košice and others. 


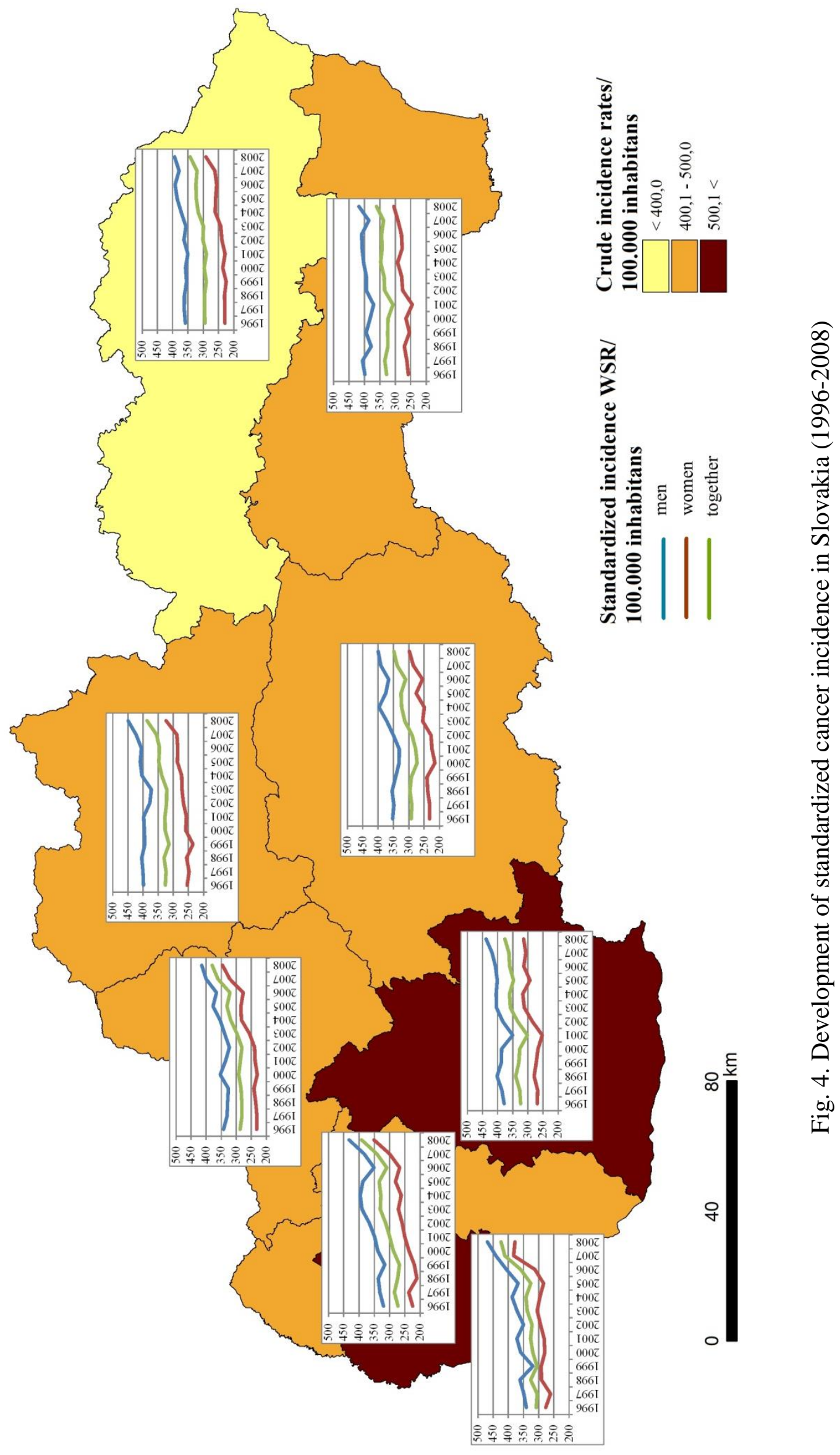




\section{CONCLUSION}

The issue of malignant cancers is very complex and it was not possible to process it in the full width, but only through selected indicators of crude and standardized incidence rate in Slovakia. Overall, we can claim that the incidence has an increasing character. The analysis of values and trends in incidence and mortality of Slovak population shows the need to intensify prevention. Programs of primary prevention and education of population must necessarily lead to the optimization of lifestyle, especially, to activities supporting non-smoking, fight against alcoholism and obesity as well as to an increase in physical activity, healthy eating, and protection against sun radiation. This measures together with quality and full screening, aimed at detecting early stages of selected cancers such as breast cancer, cervical and colorectal cancer, can change adverse development of incidence and mortality from malignant cancers [8].

The presented paper was devoted to spatial specificities of cancer mortality and incidence. The results of analyses showed that, in the structure of mortality in Slovakia, cancers maintained its second position in 1996 but also in 2013. The highest values of cancers crude mortality rate are located mainly in the western part of Slovakia e.g. Nitra and Trnava Self-governing Regions. The incidence, as another specific measurement rate, has the increasing trend in Slovakia. Development of cancer incidence in men or women is specific to each region of Slovakia. The most unfavorable situation in terms of incidence is in the Bratislava Self-governing Region which reached the highest incidence values regarding men but also women. Looking at the values of malignant cancers mortality and incidence in Slovakia, the general and sustained growth of oncological diseases in the future is evident.

The paper was elaborated within the project UGA Geographical Visualization of Cancers on the Example of the Nitra Self-governing Region and UGA VII/24/2014 Suburban Processes in the Urban parts of the Nitra City.

\section{REFERENCES}

[1] Dubcová, A. \& Kramáreková, H. Svetové choroby, Prírodné vedy v živote, Slovakia, 1998, p 176.

[2] Giannakouris J. Regional population projections EUROPOP 2008: Most EU regions face older population profile in 2030, Statistics in Focus, Luxembourg, 2011, p 350.

[3] Hewitt, M. \& Simone J. Childhood cancer survivorship: improving care and quality of life, National Academies Press, USA, 2003, pp 54-76.

[4] Hlinková, L. \& Tesař, T. Finančné náklady v kontexte farmakoterapie onkologických ochorení, Onkológia, Slovakia, 2014, vol. 9, pp. 8 - 11.

[5] Kážmer, L. \& Križan, F. Priestorové rozšírenie mortality mužov na rakovinu prostaty na úrovni okresov SR v rokoch 1996 - 2007, Acta Geografica Universitatis Comenianae, Slovakia, 2010, vol. 54, pp 101-118.

[6] Konečný, M. \& Geryk, E. \& Dítě, P. \& Trma, J. \& Kozel, J. \& Kubíček, P. \& Štampach, R. Zát'ež nádory pankreatu u české popoulace, Onkologie, Czech Republic, 2010, vol.5, pp $322-325$.

[7] Konečný, M. \& Geryk, E. \& Sedláková L. 2011. Budou dosaženy očekávané počty zhoubného melanoma, Dermatologie pro praxi, Czech Republic, 2011, vol. 5, pp 235 238. 
[8] Pleško, I. \& Dimitrová, E. \& Somogyi, J. \& Kramárová, E. \& Kiss, J. \& Vlasák, V. \& Marriot, P. Atlas výskytu zhubných nádorov v SSR, SAV, Slovakia, 2003, p 286.

[9] National Health Information Center of the Slovak republic (www.nczi.sk).

[10] Strnad, L. \& Omelčuk, A. Některé epidemiologické aspekty výskytu zhubných novotvarů ve Východočeském kraji v letech 1963-1974, Demografie, Czech Republic, 1976, vol 18, pp 233-241.

[11] Sullivan R, et al. Delivering affordable cancer care in high-income countries. Lancet Oncol, USA, 2011, vol. 10, pp 933-980.

[12] Vilinová, K. Zdravotný stav obyvatel’stva Slovenska, UKF, Slovakia, 2012, p 124. 